\title{
Peer education as a method in sexual, reproductive health promotion and risk communication for adolescent
}

\author{
Rini Harianti ${ }^{1}$, Tarbiyah Nurjanah ${ }^{2}$, Nofri Hasrianto ${ }^{3}$ \\ ${ }^{1,2,3}$ STIKes Al Insyirah Pekanbaru, Riau, Indonesia
}

\begin{abstract}
Adolescence is a period of accelerated physical, psychological, and intellectual growth and development. It includes the development in sexual maturity of adolescents. In order to promote safe and healthy sexual and reproductive health, adolescents should be equipped with adequate knowledge, attitudes, and self-efficacy regarding the matter. The role of peer influence is highest during this stgae; thus, health promotion and risk communication through peer education has shown to be effective in many settings on adolescents. The study aimed to determine the effectiveness of the peer education method as a form of health promotion in adolescent sexual and reproductive health and risk communication at SMKN "X" Pekanbaru. It was a quasiexperimental study involving 52 students. The participants were randomized into two groups, 26 in the experimental group and 26 in the control group. Data were collected using a questionnaire and analyzed by $\mathrm{t}$-test. The results showed there were significant differences in the mean changes in knowledge $(\mathrm{p}=0.000)$, attitudes $(\mathrm{p}=0.000)$, and self-efficacy $(\mathrm{p}=0.000)$ about sexual behavior in the experimental group receiving peer education compared to the control group. However, there was no significant difference in the mean changes in the role of peer influence between the two groups $(p=0.725)$. Therefore, peer education as a method in sexual and reproductive health promotion and risk communication positively changed adolescents' knowledge, attitudes, and self-efficacy about sexual behavior. Hence, it is suggested for schools to provide health promotion program regarding adolescents' sexual and reproductive health in collaboration with the Pekanbaru City Health Office and supplement it with a peer education method.
\end{abstract}

Keywords: Communication; peer education method; sexual behavior; health promotion; adolescent

\section{Peer education sebagai metode promosi kesehatan seksual, reproduksi dan komunikasi resiko pada remaja}

\begin{abstract}
ABSTRAK
Masa remaja merupakan masa percepatan pertumbuhan dan perkembangan fisik, psikologis, dan intelektual. Hal ini termasuk perkembangan kematangan seksual mereka. Untuk meningkatkan kesehatan seksual dan reproduksi yang aman dan sehat, remaja harus dibekali dengan pengetahuan, sikap, dan efikasi diri yang memadai tentang hal tersebut. Peran pengaruh teman sebaya paling tinggi selama tahap ini; dengan demikian, promosi kesehatan dan komunikasi risiko melalui pendidikan sebaya telah terbukti efektif dalam banyak situasi yag dialami remaja. Penelitian ini bertujuan untuk mengetahui efektivitas metode peer education sebagai bentuk promosi kesehatan pada kesehatan seksual dan reproduksi dan komunikasi resiko pada remaja di SMKN " $X$ " Pekanbaru. Penelitian ini merupakan penelitian kuasi-eksperimental yang melibatkan 52 siswa. Para peserta diacak menjadi dua kelompok, 26 di kelompok eksperimen dan 26 di kelompok kontrol. Data dikumpulkan dengan menggunakan kuesioner dan dianalisis dengan uji-t. Hasil penelitian menunjukkan terdapat perbedaan yang signifikan rerata perubahan pengetahuan $(p=0,000)$, sikap $(p=0,000)$ dan self-efficacy $(p=0,000)$ tentang perilaku seksual pada kelompok eksperimen yang mendapat peer education dibandingkan dengan kelompok kontrol. Namun, tidak ada perbedaan yang signifikan dalam perubahan rata-rata peran pengaruh teman sebaya antara kedua kelompok $(\mathrm{p}=0,725)$. Oleh karena itu, peer education sebagai metode dalam promosi kesehatan seksual dan reproduksi dan komunikasi risiko telah efektif dalam mengubah secara positif pengetahuan, sikap, dan efikasi diri remaja tentang perilaku seksual. Oleh karena itu, disarankan kepada pihak sekolah untuk mengadakan program promosi kesehatan tentang kesehatan seksual dan reproduksi remaja bekerjasama dengan Dinas Kesehatan Kota Pekanbaru dan melengkapinya dengan metode peer education.
\end{abstract}

Kata-Kata kunci: Komunikasi; metode peer education; perilaku seksual; promosi kesehatan; remaja

Korespondensi: Dr. Rini Harianti, S.Si., M.Si. STIKes Al Insyirah Pekanbaru, Riau, Indonesia. Parit Indah Street No.38 Pekanbaru-Riau.Email: riniharianti37@gmail.com. 


\section{INTRODUCTION}

Adolescence is a period of physical, psychological, or intellectual development and growth. Maturity of sexual function and curiosity, love of adventure, and challenges tend to take risks without thinking about the long-term consequences. Adolescents often behave like adults but psychologically do not reflect these conditions (Prasetyo, 2013). This transitional age should be wisely guided to prevent risky behavior such as pre-marital sex, criminality, and drug abuse.

Today's adolescents are surrounded by overflowing information from all directions due to openness and freedom of information. This information is readily available at any time, including information related to sexuality (Isnaeni et al., 2017). It is also argued that nowadays the adolescents' sexual behaviors are also changing, leading to a more open and accessible dating style. Kissing and making out is no longer taboo for them, even leading to premarital sex (Zainafree, 2015). This risky sexual behavior problem tends to occur at the age of 15-18 years or in their late teens because this is the time for determining their sexual identity, attracted to the opposite sex, and starting to fantasize about sex (Kemenkes RI, 2017).

The previous study showed common sexual contact done by adolescents were kissing on the cheek (50.74\%), tongue (28.9\%), neck (15.1\%), hugging (49\%), masturbation (23.2\%), touching, and sticking the genitals $(13.8 \%$ and $6.5 \%)$, oral sex $(10.1 \%)$, intercourse $(8.2 \%)$, and anal sex $(4.9 \%)$. The above-mentioned sexual contact is considered as risky sexual behavior with the absence of adequate information regarding adolescents' sexual and reproductive health to prevent negative consequences (Ulfah, 2018).

Pre-marital sexual activity is influenced by several factors, namely thoughts and feelings include knowledge, attitudes, and perceptions; personal references include parents and peers; resources include infrastructure and facilities, as well as culture (Harianti dan Nurbaiti, 2016; Rosyana et al., 2017), religion, pornographic media and norms in the society (Susmiarsih et al., 2019).

Adolescents try to acquire information regarding sex and reproductive health through friends, television, and other unscreened mass media, which often do not have high accuracy.
Adolescents should receive sex education, but in reality, parents often do not pay attention and might feel awkward in providing such information for their children. In addition, most parents believe that they should keep their children away from sexual knowledge. Most of them think that talking about sex is taboo, so that it is not worth discussing in any form and reason. However, talking and providing proper knowledge about sex can encourage teenagers to think about the risk and consequences of risky sexual behavior independently. Thus, it can prevent them from engaging in such activity. (Isnaeni et al., 2017; Khotimah \& Sari, 2018).

In addition, some parents think that puberty that occurs in adolescence is a time when a person experiences maturity related to readiness to marry and enjoy a sex life. This sex-related information is rare and never discussed with them with the assumption that keeping them away from sex information will avoid promiscuous association or sexual behavior. While the fact is, this time is the best time to inform and communicate about sexual and reproductive health. This is because the adolescent is experiencing accelerated growth in sexual development in both sexual organs and psychology, causing a solid curiosity about sex life (Isnaeni et al., 2017).

The parental role is pivotal because it will affect adolescents in preparing themselves for puberty, such as recognizing changes in physical characteristics and forming positive and negative attitudes regarding themselves and their environment. This attitude later will determine the teenager's character (Baharuddin, 2019). Overall, this will also affect their reproductive health.

Incidents regarding risky sexual behavior have been increasingly reported, such as premarital sex, pregnancy out of wedlock, early marriage, and poor knowledge of reproductive health among adolescents. This sexual and reproductive health problem often occurs due to the limited access to information, advocacy, lack of access to youth-friendly services, and the uneven distribution of reproductive health curricula at the school level. This information can be delivered through peer educators, a program and process of mentoring for adolescents carried out from/by/for them following the local norms and culture prevailing in their community. (Pratiwi et al., 2019). 
Adolescent sexual behavior is influenced by their knowledge (Darmasih, 2011). The lack of knowledge about sexual behavior results in pre-marital sexual relations without knowing how to protect themselves from problems such as unwanted pregnancies, unsafe abortions, HIV/AIDS, and various other sexually transmitted diseases (STDs). It is our collective task to prevent such mishaps. Therefore, sexual education, especially about pre-marital sex in adolescents, is needed (Khotimah \& Sari, 2018).

Knowledge indirectly affects adolescents' sexual behavior through norms, values, selfefficacy, attitudes, and perspectives. For example, parental ignorance about sex leads these adolescents to obtain such information through friends and mass media (print, electronic, and online) (Rinta, 2015).

In this study, we limit the definition of sexual and reproductive health to adolescents' risky sexual behavior, which encourages adolescents to have sexual contact with the opposite sex or same-sex before marriage. Factors that cause this risky sexual behavior in adolescents include lack of knowledge about reproductive health, the spread of inaccurate/ false information, and sexual stimulation through mass and social media. Adolescents are naturally curious to know, try and imitate what they see and hear. This curiosity includes sex and sexuality, leading them to risky sexual behavior without understanding the future risks of such action.

Self-efficacy is the belief in one's ability to perform an action or control certain conditions. Self-efficacy affects behavioral mechanisms; believing one's ability to produce or excel in something will lead one to pursue the goal. Adolescents with high self-efficacy will prevent them from engaging in risky sexual behavior. Nevertheless, on the contrary, adolescents with low self-efficacy tend to engage in harmful sexual behavior that will negatively affect themself, their families, and society (Murhadi \& Kurniawati, 2019).

Peer educators are found to influence and be a model for adolescents in behaving with their partners (Suwarni, 2016; Lubis, 2017). Hence, peer education is considered a priority strategy. Someone from the target group is trained to be a liaison or a network in the system for other members of the target groups or their peers to effectively develop, encourage, support, and promote healthy behavior (Winarti \& Ernawati, 2019).

The previous survey conducted in the study site, the SMKN "X" Pekanbaru, showed the presence of several risky sexual behaviors, namely, students were found making out, hugging, and kissing at school. Against the background, it is considered necessary to conduct sexual and reproductive health promotion aimed at adolescents to improve their knowledge, attitudes, and skill to protect themselves from sexual behavior that will harm them (Rahayu, 2008). The health promotion for behavioral change communication is influenced by the material to be delivered, the use of equipment and methods, and the person who will deliver it (Notoadmodjo, 2012).

Peer education can be utilized as a method to deliver sex education for adolescents in order to prevent risky sexual behavior. They can convey the process of communication, information, and education (IEC) regarding sex education to each other comfortably, which can bridge the gap between knowledge, attitudes, behavior, and health education. It can also motivate adolescents to receive the correct information and be knowledgeable about building a more positive attitude and behavior regarding sexual and reproductive health. Peer education for adolescents is considered adequate because teenagers tend to have a closer relationship and use the same language. In addition, it can be done anywhere and anytime without having to be afraid because the delivery can also be done in a relaxed manner, more comfortable when discussing sensitive matters about the problems they face (Astari \& Fitriyani, 2019).

This approach is expected to change adolescents' behavior because of their interactions (Rofi'ah et al., 2017). Moreover, a study has shown significant differences in changes in attitudes of SMKN 1 students in Stabat Langkat Regency receiving peer education (Mardiah, 2016). Considering the need for health promotion regarding sexual and reproductive health to prevent risky sexual behavior among adolescents in SMKN "X" Pekanbaru and the central role of peer education, this research aimed to analyze the effectiveness of health promotion related to sexual behavior and reproductive and risk communication through peer education to increase knowledge, attitudes, self-efficacy, and peer educator among 
adolescents in SMKN "X" Pekanbaru.

\section{RESEARCH METHODS}

The is a quasi-experimental study, carried out at SMKN "X" Pekanbaru. The calculated maximum sample size for this study was 26 students in the intervention group and 26 students in the control group; thus, the total sample required was 52 students. The participants were recruited from class XI at SMKN "X" by proportional simple random sampling method. A lottery was drawn in each class XI at SMKN "X" Pekanbaru. The sample size distribution is calculated by the number of students in each class divided by the total number of students multiplied by the proportion. The inclusion criteria for the study participants were as follows: students from class XI of SMKN “X” Pekanbaru, aged 16-17 years, willing to participate in the study. Students who were sick and did not participate in the study 2 times in a row were excluded.

Participants were divided equally into two groups. Group 1, the experimental group, received peer education counseling. Peer educators should meet the following criteria: having a trustworthy nature, honest, caring or empathetic, confident and intelligent, and able to communicate well with their friends. The experimental group received intervention from the peer educators three times for two weeks and two times for sharing and discussion in one week. Group 2 or the control group did not receive peer education. The peer educators have been trained beforehand to meet the criteria determined by the researcher.

This study utilized primary and secondary quantitative data. Primary data were collected through a written questionnaire directly from the participants. At the same time, Secondary data was obtained from SMKN "X" Pekanbaru administration. The secondary data consists of the number of students, student identities, and student contacts.

The initial stage of data collection is in coordination with the school, coordinating with the Deputy Principal of the Student Affairs regarding the research, interventions, and data collection. Preliminary data on cases of risky sexual behavior that occurred in SMKN " $X$ " Pekanbaru were collected from interviews with teachers and the students themselves. Then, to identify potential peer educators, the research team communicated with the homeroom teacher at SMKN "X" Pekanbaru based on the criteria set by the researcher. After selecting peer educators, the researchers provided training and guidance to the peer educators by providing some material on adolescent sexual behavior until they mastered the material.

The independent variable in this study was the treatment variable, namely the peer education method, while the dependent variables were changes in knowledge, attitude, self-efficacy, and role of peer influence. Level of knowledge was defined as any information that the students acquire about sexual behavior, including their understanding of sexual behavior, types of sexual behavior, and consequences. The attitude was defined as an attitude toward negative or positive statements regarding sexual behavior. Self-efficacy was defined as perceived efficacy and self-esteem to influence choices, goals, problem solving regarding adolescent sexuality. The role of peer educators was defined as adolescents' perceptions on the role of peer educators in affecting adolescents' sexual behavior related to invitations, closeness, sources of information, and perceptions.

The research instrument used was a questionnaire comprising 75 questions in total. There were 15 items on level of knowledge, 15 items on attitudes, 15 items on self-efficacy, 15 items on the role of peer educators, and 15 items on behavior regarding adolescent sexual activity using the Guttman scale.

The measurement of the knowledge variable was in an interval scale based on the score from 15 questions with the alternative answers of a, b, c, and d. The score's weight was 1 for the correct answer and 0 for the wrong answer. The minimum score obtained was 0 , and the maximum value obtained was 15 .

Questionnaires with positive statements were found in questions no. 1, 3, 6, 8, 9, 10, and 13. While for negative statements, the answer strongly agree was given a score of 1 , agree was given a score of 2 , disagree was given a score of 3, and strongly disagree was given a score of 4 , with negative statements found in questions no. $2,4,5,7,11,12,14$, and 15 . Measurement of students' attitudes was also an interval scale based on the total score from 15 questions with the answer choices strongly agreeing being given a score of 4 , agreeing being given a score of 3 , disagreeing being given a score of 
2, and strongly disagree given a score of 1 for a positive statement. This results in the highest score being $4 \times 15=60$, and the lowest score was $1 \times 15=15$.

Measurement of students' self-efficacy regarding adolescent sexual behavior was an interval scale from 15 questions. Questionnaires with positive statements were found in questions no. $1,2,3,7,8,9,10,13,14$, and 15 . The answer strongly agree was given a score of 4 , agree was given a score of 3 , disagree was given a score of 2 , and strongly disagree was given a score of 1 for a positive statement. While for negative statements, the answer strongly agree was given a score of 1, agree was given a score of 2 , disagree was given a score of 3 , and strongly disagree was given a score of 4 , with negative statements were found in questions no $4,5,6$, 11 , and 12 so that the highest score was $4 \times 15=$ 60 and the lowest score was $1 \times 15=15$.

Peer educator measurement of students' adolescent sexual behavior was an interval scale derived from 15 questions. The answer strongly agree was given a score of 4 , agree was given a score of 3 , disagree was given a score of 2 , and strongly disagree was given a score of 1 for a positive statement. Questionnaires with positive statements were found in questions no. $3,9,11,13,14$, and 15 . For negative statements, the answer strongly agree was given a score of 1 , agree was given a score of 2, disagree was given a score of 3 , and strongly disagree was given a score of 4 . Negative statements were found in questions no. $1,2,4,5,6,7,8$, and 12 so that the highest score was $4 \times 15=60$ and the lowest score was 1 x $15=15$.

Data processing in this study consisted of several stages, namely data editing, data coding, scoring, data entry, cleaning, and tabulating the data. The data were analyzed descriptively and inferentially. Univariate analysis was used to describe each variable's frequency distribution and proportion. At the same time, bivariate analysis was utilized to determine the effect of the peer educator method on the dependent variables. Bivariate analysis was conducted using a t-test.

\section{RESULTS AND DISCUSSION}

The distribution of participants includes age and gender (Table 1).

Table 1 shows that the majority $(53.85 \%)$
Table 1 Distribution of Objects by Age and Gender

\begin{tabular}{llll}
\hline & $\begin{array}{l}\text { Experiment } \\
\text { Variable }\end{array}$ & $\begin{array}{l}\text { Control } \\
\mathrm{n}(\%)\end{array}$ & $\mathrm{P}$ \\
\hline $\begin{array}{l}\text { Age } \\
\text { (years) }\end{array}$ & & & \\
16 & $14(53.85)$ & $13(50)$ & 0.781 \\
17 & $12(46.15)$ & $13(50)$ & \\
Gender & & & \\
Male & $14(53.85)$ & $\begin{array}{l}14 \\
(53.85)\end{array}$ & 1.000 \\
& & $\begin{array}{l}12 \\
(46.15)\end{array}$ & \\
Female & $12(46.15)$ & \\
\hline
\end{tabular}

Source: Research results, 2020

of students from the experimental group are 16 years old, while in the control group, half $(50 \%)$ of them are 16 years old, and the rest was 17 years old. The distribution of gender in control and experimental groups were the same, $53.85 \%$ for males and $46.15 \%$ for females. The difference in the distribution of the participants' characteristics was not statistically significant between the experimental and the control group. This means the distribution of subjects was homogeneous in terms of age and sex.

Table 2 shows that the majority $(88.5 \%)$ of subjects in the experimental group experienced an increase in knowledge about sexual behavior to "good" after receiving the intervention. While in the control group, $46.2 \%$ had only "enough" knowledge. The majority (65.4\%) of subjects in the experimental group had a positive attitude compared to $53.8 \%$ in the control group. The majority (73.1\%) of students in the experimental group had a positive selfefficacy compared to only $53.8 \%$ in the control group. On the contrary, the majority $(73.1 \%)$ of students in the control group perceived the role of peers educators had a strong effect compared to $53.8 \%$ in the experimental group.

The results of the analysis of different tests before, after, and the difference in the level of knowledge, attitudes, self-efficacy, and peer educator of SMKN "X" Pekanbaru students about sexual behavior in each treatment group (Table 3).

TKet: ${ }^{1}$ In the same column, numbers with different letters indicate that there is a significant difference between treatment groups $(p<0.05)$ 
Table 2 Distribution of Knowledge, Attitudes, Self-Efficacy, and Peer Educators' role Before and After Intervention in both groups

\begin{tabular}{|c|c|c|c|c|c|}
\hline \multirow{3}{*}{ No } & \multirow{3}{*}{ Variable } & \multicolumn{2}{|c|}{ Experiment } & \multicolumn{2}{|l|}{ Control } \\
\hline & & Before & After & Before & After \\
\hline & & $\mathrm{n}(\%)$ & $\mathrm{n}(\%)$ & $\mathrm{n}(\%)$ & $\mathrm{n}(\%)$ \\
\hline \multirow[t]{4}{*}{1} & Knowledge & & & & \\
\hline & Good & 7 (26.9) & $23(88.5)$ & $3(11.5)$ & 7 (26.9) \\
\hline & Enough & $10(38.5)$ & $3(11.5)$ & $12(46.2)$ & $12(46.2)$ \\
\hline & Not enough & $9(34.6)$ & $0(0)$ & $11(42.3$ & $7(26.9$ \\
\hline \multirow[t]{3}{*}{2} & Attitude & & & & \\
\hline & Positive & $13(50)$ & $17(65.4)$ & $15(57.7)$ & $14(53.8)$ \\
\hline & Negative & $13(50$ & $9(34.6)$ & $11(42.3)$ & $12(46.2)$ \\
\hline \multirow[t]{3}{*}{3} & Self Efficacy & & & & \\
\hline & Positive & $13(50)$ & $19(73.1)$ & $17(65.4)$ & $14(53.8)$ \\
\hline & Negative & $13(50$ & 7 (26.9) & $9(34.6)$ & $12(46.2)$ \\
\hline \multirow[t]{4}{*}{4} & Peer & & & & \\
\hline & Influence & $15(57.7)$ & $14(53.8)$ & $17(65.4)$ & $19(73.1)$ \\
\hline & Strong & $11(42.3)$ & $12(46.2)$ & $9(34.6)$ & 7 (26.9) \\
\hline & Weak & & & & \\
\hline
\end{tabular}

Source: Research results, 2020

with dependent t-test; significantly different with $p<0.05$ between treatments (independent t-test); ${ }^{2}$ In the same column, numbers with different letters indicate that there is a significant difference between treatment groups $(p<0.05)$ with dependent t-test; significantly different with $p<0.05$ between treatments (independent t-test); ${ }^{3}$ In the same column, numbers with different letters indicate that there is a significant difference between treatment groups $(p<0.05)$ with dependent t-test; significantly different with $p<0.05$ between treatments (independent t-test); ${ }^{4}$ In the same column, numbers with different letters indicate that there are significant differences between treatment groups $(\mathrm{p}<0.05)$ with dependent t-test; significantly different with $\mathrm{p}<0.05$ between treatments (independent t-test).

Table 3 shows that the difference in the mean value of students' knowledge about sexual behavior between the experimental and control group was significant $(p=0.000)$. Likewise, the mean difference in students' attitudes and selfefficacy regarding sexual behavior also showed significant results with a p-value of 0.000 . However, peers' role in influencing sexual behavior was not showing significant results with a p-value of 0.725 .

The results showed a change in knowledge, attitude, and self-efficacy before and after the peer educator method was given. A study showed an increase in the knowledge of high school students about sexual behavior after receiving a lecture method (Mardiah, 2016). Similar results reported a significant increase in student sexual behavior at SMK Abdurabb, Pekanbaru City, Province. In addition, another study found a significant effect of the peer education method as a form of health education in increasing the knowledge and attitudes of correctional residents about HIV/AIDS (Marlita, 2017).

Kasih L C reported a significant interaction between the attitudes of adolescents who received sex education and those who did not receive sex education by peer educators, thus signifying the vital role of peer education to increase healthy behavior (Kasih, 2016). The lack of information and education about adolescent sexuality led to poor knowledge on sexuality. Students do not know the impact of having free sex. Students also do not know the type of disease as a risk from unsafe sex. Many cases of pre-marital sex occur due to the lack of students' knowledge about sexuality. 
Table 3 The Average Value of Knowledge, Attitudes, Self-Efficacy and the Effect of Peer Subjects in Each Treatment

\begin{tabular}{cccc}
\hline & Control & Experiment & \\
\cline { 2 - 3 } Variable & $($ Mean \pm SD $)$ & $($ Mean \pm SD $)$ & \\
\hline Knowledge $^{1}$ & & & \\
Before & $8.96 \pm 2.25 \mathrm{a}$ & $9.65 \pm 2.50 \mathrm{a}$ & \\
After & $10.12 \pm 2.14 \mathrm{~b}$ & $12.92 \pm 1.2 \mathrm{~b}$ & \\
difference & $1.15 \pm 0.97$ & $3.27 \pm 2.33$ & $0.000^{* *}$ \\
Attitude & & & \\
Before & $50.54 \pm 3.15 \mathrm{a}$ & $50.62 \pm 4.02 \mathrm{a}$ & \\
After & $50.77 \pm 2.98 \mathrm{a}$ & $56.19 \pm 2.60 \mathrm{~b}$ & \\
difference & $0.23 \pm 1.61$ & $5.58 \pm 2.86$ & $0.000^{* *}$ \\
Self-efficacy & & & \\
Before & $47.19 \pm 4.95 \mathrm{a}$ & $51.27 \pm 3.95 \mathrm{a}$ & \\
After & $59.23 \pm 7.69 \mathrm{~b}$ & $59.23 \pm 7.70 \mathrm{~b}$ & \\
difference & $0.04 \pm 0.66$ & $7.96 \pm 9.36$ & $0.000^{* * *}$ \\
Peer influence & & & \\
Before & $46.42 \pm 4.18 \mathrm{a}$ & $46.42 \pm 4.19 \mathrm{a}$ & \\
After & $55.65 \pm 2.09 \mathrm{~b}$ & $55.65 \pm 2.10 \mathrm{~b}$ & \\
difference & $7.31 \pm 27.36$ & $9.23 \pm 4.26$ & 0.725 \\
\hline
\end{tabular}

Adequate information obtained through sex education can become a shield in controlling the great curiosity that often arises during adolescence. This accurate information can prevent them from engaging in risky sexual behavior such as pre-marital sex. This information can be conveyed in a simple form to be easily understood and accepted by adolescents. Some immediately understand through one delivery of the material, but some have to listen repeatedly before understanding it. This gap in understanding makes it difficult to provide broad sexual education that all adolescents can generally accept, especially in schools. However, this should not be used as an excuse to avert adolescents from receiving sex education. All the information provided to teenagers regarding sexual and reproductive health is actually to curb their curiosity and find out from other untrusted sources (Rinta, 2015).

Providing information is a strategy to change behavior. Increased knowledge, attitudes, and practice will be accompanied by awareness in attitude and action (Notoadmodjo, 2012). Efforts to provide information in this study were carried out through counseling. The process of empowering the community to play an active role in changing behavior and the environment and maintaining and improving health is known as health promotion.

Attitude is developed and learned as long as a person studies an object. Attitude is only a tendency to take action on the object in a certain way. Therefore, the views, assumptions, judgments, and feelings that arose from a stimulus or object followed by a tendency to act are expressed as an attitude. (Notoadmodjo, 2012). The change in student attitudes before and after the intervention was significant in the intervention group. Peer education is a system of delivering sex education through peer educators to provide information about health in a sustainable, voluntary, and appropriate manner. In this study, the learning process produces a learning outcome: the increase in the subject's knowledge of sexual behavior.

In this study, counseling utilizing the peer education method is a stimulus or object that can eventually affect the subject under study to act following the message conveyed. Counseling with the peer education method is changing attitudes that require adequate preparation and knowledge for both the instructor and their target audiences. Peer educators have been 
appointed as counselors to educate students about sexual behavior to change the attitudes of their peers after counseling.

Rosenberg's theory states interaction between knowledge and attitudes consistently. If the cognitive component (knowledge) changes, there will also be a change in attitude. Based on the above, the increase in the knowledge score of the subject in this study after receiving the intervention from the peer education method was followed by an increase in the attitude score. The increase in the positive attitude of adolescents toward sexual behavior will influence their response to early sexual behavior/contact and pre-marital sex (Rinta, 2015).

This mechanism can be carried out in the following ways: (a) Involving youth to provide positive energy to those in need and filling their free time with beneficial activities. Usually, the tendency to engage in risky sexual behavior occurs because of great curiosity and excessive free time. Adolescents in this transition period are constantly faced with curiosity about various things. Not infrequently, this curiosity is not well answered by parents, teachers, and the environment. This led the adolescents to look for answers on their own from untrustworthy or misleading sources such as pornographic sources from the internet. In the end, teenagers who have less knowledge about sex education will spend their time accessing pornographic things and vent their curiosity through unhealthy sexual behavior. The results of statistical tests in this study showed no change in attitude in the control group, (b) Inviting adolescents to abstain from free sex and extramarital sex and its negative impacts. Hopefully, through information and understanding about the risks and responsibilities, they will be able to control themselves in matters relating to sexuality caused by their developing hormones (Rinta, 2015).

The increase in incidents of risky sexual behavior among adolescents' overtime has caused concern, especially in late adolescence. They tend to be more permissive towards premarital sex because of the opportunities for courtship activities that lead to sexual contact. On the other hand, there has been a shift in moral values so that such behaviors are now considered normal (Zainafree, 2015). What a person experiences will affect his/her response to social stimuli. In addition, a strong appreciation of social stimuli must also be advocated so that responses and appreciation become one of the bases for the formation of healthier attitudes (Azwar, 2005).

Seeing the above phenomenon that continues to grow, it takes special attention from parents to prevent the possible consequences that will arise. Parents can make efforts in the family to provide correct information about sex. Communication between parents and children, in this case, is needed to provide guidance for adolescents regarding changes occurring in adolescents both physically and psychologically. When effective communication has been established between the two, adolescents can easily accept what their parents say so that the problems they experience can be discussed together, and adolescents will also be more effective in developing aspects of human activity in general, namely both individually, social and more (Supratiwi et al., 2011).

This is in line with the difference in the mean score of students' knowledge about sexual behavior between the intervention and the control group, which was significant with a $\mathrm{p}$-value of 0.000 . The difference in the values of attitudes and students' self-efficacy about sexual behavior also showed significant results with a $\mathrm{p}$-value of 0.000 . However, it was not significant for the influence of students' peers on sexual behavior with a p-value of 0.725 . This happens because of the increase in student knowledge, so there is also an increase in student attitudes. The process of changing attitudes requires peer educators to play a role in providing material to students about sexual behavior so that attitudes change after counseling. Knowledge and attitude must be consistently related. If the knowledge component changes, it is followed by changes in attitude. Self-efficacy is a form of one's own ability to carry out certain behaviors, the ability to assess oneself, motivate oneself to act to obtain the desired goals (Ormrod, 2008). There is an increase in self-efficacy towards the sexual behavior of SMKN "X" Pekanbaru students through the peer education method.

A study in other setting showed that the peer education method and audio-visual media have a significant influence on pre-marital sex for young women in SMA Negeri 1 Pulau Tunjung, Dharmasraya Regency (Khotimah \& Sari 2018); also, the self-efficacy of students at 
SMK Asyifa Banda Aceh significantly affected their sexual behavior (Murhadi \& Kurniawati (2019).

Self-efficacy is an aspect of self-knowledge that is very influential in an individual's life. One's self-efficacy can influence their attitudes and actions to achieve the desired goals, including considering all the risks that might occur. Adolescents who have good self-efficacy tend to avoid engaging in risky sexual behavior, while adolescents who had pre-marital sexual relations tend to have low self-efficacy and lack knowledge about sex. (Murhadi \& Kurniawati, 2019).

Individuals with high self-efficacy will feel confident in overcoming all problems that they experience. Self-efficacy can be developed from the personality of each student. High selfefficacy in students can affect every action and decision taken. This is where peers are needed as a source of knowledge and positive pressure.

Closeness to their peer group occurs because they can replace family ties, and there is affection, sympathy, and mutual understanding to a means of sharing experiences, anatomy, and independence (Darmayanti. et al., 2011). The active function of peers is due to the fact that most subjects have a peer group. This peer group can create closeness, mutual understanding, and information sharing. Therefore it is easier to share experiences and communication risk from unhealty sexual behavior without shame or stigma.

The peer education method did not affect adolescent sexuality behavior at SMKN " $X$ " Pekanbaru. This is in contrast to another study stating that the influence of peers plays a role in overcoming the negative sexual behavior of students at SMK Adurab Pekanbaru, Riau (Marlita, 2017). Delivering information about sexual behavior can be done by peers, but with a note that there is two-way communication between them so that the results obtained are significant. The sensitive and personal nature of sexual behavior also hinders active communication with peers.

Peer groups can influence behavior either positively or negatively. Positive influence can be interpreted as valuable activities such as forming study groups and obeying the norms that apply in society, while negative influence can be in the form of violation of social norms. Therefore, one of the functions of peers is as a source of knowledge, problem-solving, and learning.

In general, there is a significant positive effect of the peer education method in increasing students' knowledge, attitudes, and self-efficacy about adolescent sexual behavior. This signifies that the peer education method is effective for health education, especially in preventing adolescents from engaging in risky sexual behavior by providing comprehensive information about sexual behavior.

The peer education method is effective because peers carry out the process in the group, namely their friends with almost the same or equivalent characteristics, the language used is the same, with a relaxed way of delivery, so that the target group is more comfortable discussing sensitive issues so that their communication becomes more open and effective. The learning process in peer educators also actively involves participants so that all information obtained will be sustainable.

\section{CONCLUSION}

It can be concluded that in the experimental group, there was a significant increase in knowledge and changes in attitude and selfefficacy on adolescent sexual behavior in students receiving peer education compared to the control group. Therefore, peer education as a method in sexual and reproductive health promotion and risk communication positively changed adolescents' knowledge, attitudes, and self-efficacy about sexual behavior. Hence, it is suggested for schools to provide health promotion program regarding adolescents' sexual and reproductive health in collaboration with the Pekanbaru City Health Office and supplement it with a peer education method.

\section{REFERENCES}

Astari, R., \& Fitriyani, E. (2019). Pengaruh peer education terhadap pengetahuan dan sikap remaja tentang pencegahan hivaids di SMK Korpri Majalengka. Jurnal Ilmu Kesehatan Bhakti Husada: Health Sciences Journal, 10(2), 150-159. https:// doi.org/10.34305/jikbh.v10i2.93

Baharuddin.(2019).Pentingnyapolakomunikasi 
orang tua terhadap perkembangan pubertas remaja. Jurnal Studi Gender Dan Anak, 12(1), 610-621. https://doi. org/10.30994/10.30994/vol1iss1pp16

Darmayanti., Y., Lestari, Y., Rama, M., \& Dani. (2011). Peran teman sebaya terhadap perilaku seksual pra nikah siswa SLTA Kota Bukittinggi.Jurnal Kesehatan Masyarakat, 6(1), 24-27.

Harianti, R., \& Nurbaiti. (2016). Karakteristik, pengetahuan dan sikap pasangan usia subur tentang penyakit menular seksual di klinik "Y" Kabupaten Indragiri Hulu. Jurnal Kesehatan Reproduksi, 7(3), 199-209.

Isnaeni, N., Laksono, B., \& Deliana, S. M. (2017). Hubungan antara pengetahuan, pola asuh permisif, tayangan pornografi, dan konformitas teman sebaya dengan perilaku seks remaja yang menggunakan jasa wps (wanita penjaja seks) di Bandungan Kabupaten Semarang. Public Health Perspective Journal, 2(1), 34-71.

Kasih, L. C. (2016). Efektifitas peer education pada pengetahuan dan sikap siswa sma dalam pencegahan hiv / aids the effectivity of peer education on students ' knowledge and attitude in preventing the spreading hiv / aids yang menyerang system kekebalan tubuh tidak seksualit. Jurnal Ilmu Keperawatan, 4(2), 26-33.

Kemenkes RI. (2017). Situasi kesehatan reproduksi remaja. In Situasi Kesehatan Reproduksi Remaja (Issue Remaja, pp. 1-8). https://www.kemkes.go.id/download. php?file $=$ download/pusdatin/infodatin/ infodatin reproduksi remaja-ed.pdf

Khotimah, S., \& Sari, E. N. (2018). Perbedaan efektivitas metode peer education dan media audio visual terhadap pengetahuan dan persepsi remaja mengenai seks pranikah. JOMIS (Journal of Midwifery Science), 2(1), 26-31.

Lubis, D. P. U. (2017). Peran teman sebaya dan paparan media pornografi terhadap perilaku seksual remaja di sekolah tinggi ilmu kesehatan Yogyakarta. Jurnal Kesehatan Samodra Ilmu, 8(1), 47-54.

Mardiah. (2016). Pengaruh metode ceramah dan peer education terhadap pengetahuan dan sikap remaja tentang perilaku seksual di SMK Negeri 1 Stabat Tahun 2015.

Marlita, L. (2017). Pengaruh peer education terhadap perilaku seksual remaja di SMAK Abdurrab Kota Pekanbaru Provinsi Riau. Jurnal Keperawatan Abdurrab, 1(1), 7181.

Murhadi, T., \& Kurniawati, E. (2019). Pengaruh faktor Efikasi Diri Terhadap Perilaku Seksual Remaja SMK Kesehatan Assyifa School Banda Aceh. Journal of Healthcare Technology and Medicine, 5(2), 239-246.

Prasetyo, D. (2013). Pengaruh kecerdasan emosional dan perilaku belajar terhadap prestasi akademik mahasiswa jurusan akuntansi Universitas Brawijaya. Jurnal Ilmiah Mahasiswa FEB, 2(1), 1-15.

Pratiwi, I. G. D., Mulyadi, E., \& Hasanah, L. (2019). Pembentukan peer educator dan pemberian informasi tentang kesehatan reproduksi pada siswa siswi di MA Maslahatul Hidayah di Desa Errabu Kecamatan Bluto. Jurnal Abdiraja, 2(2), $30-33$.

Rinta, L. (2015). Pendidikan seksual dalam membentuk perilaku seksual positif pada remaja dan implikasinya terhadap ketahanan psikologi remaja. Jurnal Ketahanan Nasional, 21(1), 163-174.

Rofi'ah, S., Widatiningsih, S., \& Vitaningrum, D. (2017). Kesehatan metode peer group terhadap tingkat pengetahuan dan sikap personal hygiene saat menstruasi. Jurnal Ilmiah Bidan, 2(2), 31-36.

Rosyana, K., Kusnanto, \& Wahyuni, E. D. (2017). Analisis faktor yang berhubungan dengan perilaku seks bebas pada remaja di SMK DR Soetomo Surabay Berdasarkan Teori Perilaku WHO. Jurnal Kesehatan Samodra Ilmu, 1(1), 12-17.

Supratiwi, M., Makmuroch, \& Andayan, T. R. (2011). Perilaku seksual remaja ditinjau dari efektivitas komunikasi dengan orang tua dan kontrol diri di SMA 5 Surakarta. Wacana, 3(1), 1-20. jurnalwacana. psikologi.fk.uns.ac.id/index.php/wacana/ article/view/45/45

Susmiarsih, T. P., Marsiati, H., \& Endrini, S. (2019). Peningkatan pengetahuan faktorfaktor yang memengaruhi perilaku seks dalam upaya cegah seks pranikah pada siswa-siswi SMPN 77 dan SMAN 77 Jakarta Pusat. 4(2), 206-213.

Ulfah, M. (2018). Faktor-faktor yang mempengaruhi perilaku seksual pranikah 
pada smp dan sma di wilayah eks- Kota Administratip Cilacap. Jurnal Ilmiah IlmuIlmu Kesehatan, 16(3), 137-142.

Winarti, Y., \& Ernawati, R. (2019). Effectiveness of peer education method in increasing knowledge and attitude towards hiv/aids prevention among students in Samarinda. IJNP (Indonesian Journal of Nursing Practices), 3(2), 105-110. https://doi. org/10.18196/ijnp.32100

Zainafree, I. (2015). Perilaku seksual dan implikasinya terhadap kebutuhan layanan kesehatan reproduksi remaja di lingkungan kampus (studi kasus pada mahasiswa Universitas Negeri Semarang). Unnes Journal of Public Health, 4(3), 1-7. https:// doi.org/10.15294/ujph.v4i3.6337 